\title{
Pengaruh Kecerdasan Interpersonal dan Penguasaan Diksi terhadap Kemampuan Menulis Cerita Pendek
}

\author{
Homsaniwati \\ Fakultas Pascasarjana Universitas Indraprasta PGRI \\ Jalan Nangka No. 58 C/TB. Simatupang, Tanjung Barat, Jakarta Selatan 12530 \\ homsaniwati@gmail.com
}

\begin{abstract}
This survey research aims to find and analyze interpersonal intelligence and mastery of diction together / partially on the ability to write short stories. Affordable population in this study were students of class XI in State Senior High Schools in Gambir, Central Jakarta, as many as 60 respondents. The research sample was obtained through a simple random sampling method. The research design used through interaction techniques with three variables consisting of two independent variables, namely interpersonal intelligence, and diction mastery and one competency variable, namely the ability to write short stories. Data collection was carried out using questionnaires and objective test techniques and written for all variables. The data collected subsequently uses multiple linear regression and collection techniques. The results showed that there was a significant difference between interpersonal intelligence and mastery of diction both together and fully on the ability to write short stories.
\end{abstract}

Keywords: interpersonal intelligence, diction, writing, short story

\begin{abstract}
Abstrak
Penelitian survei ini bertujuan untuk menemukan dan menganalisis secara empiris pengaruh kecerdasan interpersonal dan penguasaan diksi secara bersama-sama/parsial terhadap kemampuan menulis cerita pendek. Populasi terjangkau pada penelitian ini adalah siswa kelas XI pada Sekolah Menengah Atas Negeri di Kec. Gambir, Jakarta Pusat, sebanyak 60 responden. Sampel penelitian diperoleh melalui metode simple random sampling. Rancangan penelitian yang digunakan melalui teknik korelasi dengan tiga variabel yang terdiri atas dua variabel bebas, yaitu kecerdasan interpersonal dan penguasaan diksi serta satu variabel terikat, yaitu kemampuan menulis cerita pendek. Pengumpulan data dilakukan dengan teknik kuesioner serta tes obyektif dan tertulis untuk semua variabel. Data yang terkumpul selanjutnya menggunakan teknik korelasi dan regresi linier berganda. Hasil penelitian menunjukkan bahwa terdapat pengaruh yang signifikan kecerdasan interpersonal dan penguasaan diksi baik secara bersama-sama maupun secara tersendiri terhadap kemampuan menulis cerita pendek.
\end{abstract}

Kata Kunci: kecerdasan interpersonal, diksi, menulis, cerita pendek

\section{PENDAHULUAN}

Bahasa punya peran sentral terhadap tumbuh-kembang sosial, intelektual, dan emosional siswa. Bahasa mampu memberi kontribusi atas keberhasilan dalam proses belajar-mengajar. Menurut (Arifin \& Tasai, 2009), bahasa Indonesia sebagai bahasa negara berfungsi sebagai: 1) Bahasa resmi kenegaraan; 2) Bahasa pengantar dalam dunia pendidikan; 3) Alat perhubungan pada tingkat nasional untuk kepentingan perencanan dan pelaksanaan pembangunan, dan 4) Alat pengembangan kebudayaan, ilmu pengetahuan, dan teknologi. Pembelajaran bahasa Indonesia seyogyanya mampu membantu siswa mengenal lingkungan atau 
orang lain, memahami budaya, menyampaikan gagasan dan perasaan, serta berpartisipasi dalam penggunaan bahasa tersebut. Artinya, dengan bahasa, siswa dapat menggunakan kekuatan analitis dan imajinatifnya, baik dalam kemampuan berbicara, maupun dalam kemampuan menulis.

Bahasa adalah ucapan, pikiran, dan perasaan seseorang yang teratur antara anggota masyarakat, berupa simbol bunyi yang merupakan hasil alat ucap manusia yang fungsi utamanya adalah untuk berkomunikasi, berinteraksi (fungsi sosial), menyampaikan pikiran atau menyatakan diri, konsep, gagasan, juga perasaan (fungsi ekspresi). Selain itu, bahasa bagi manusia juga berfungsi imajinasi, yaitu membayangkan sesuatu dengan lintas waktu dan tempat. Imajinasi merupakan aspek perkembangan perilaku manusia.

Pada Kurikulum 2013, banyak materi yang berkaitan dengan kegiatan menulis. Salah satunya adalah materi tentang memproduksi teks cerita pendek. Dalam kompetensi ini, siswa diharapkan mampu menghasilkan teks cerita pendek secara tepat. Salah satu kesulitan siswa adalah menyampaikan gagasan atau ide-ide dalam waktu yang relatif singkat. Pembelajaran menulis merupakan kegiatan pembelajaran yang memerlukan perhatian khusus oleh guru mata pelajaran. Selama ini, pembelajaran menulis masih banyak disajikan dalam bentuk teori. Hal tersebut yang mengakibatkan siswa kurang terbiasa untuk menulis sehingga berakibat pada sulitnya menuangkan ide secara tertulis. Kurangnya praktik menulis ini merupakan salah satu faktor kurangnya keterampilan siswa dalam menulis. Akhadiah menyatakan bahwa menulis merupakan kemampuan kompleks yang tidak terlepas dari pengetahuan dan keterampilan pengetahuan dan keterampilan (Akhadiah, Arsjad, \& Ridwan, 1988).

Kompetensi menulis dalam pengajaran berbahasa dan bersastra adalah tataran yang tersulit (memerlukan keterampilan berpikir logis dan bernalar) dari tiga kompetensi lainnya, yaitu mendengarkan, membaca, dan berbicara. Sebelum siswa diajarkan kemampuan menulis, banyak prasyarat yang harus sudah dimiliki oleh siswa. Prasyarat yang dimaksud adalah kemampuan kebahasaan yang harus dimiliki bukan sekadar kemampuan bidang pengetahuan berbahasa dan bersastra, tetapi lebih pada kemampuan yang sifatnya praktis.

Kondisi yang ada di lapangan menunjukkan bahwa pengajaran bahasa Indonesia belumlah tertangani dengan baik, terutama dalam pembelajaran menulis. Guru dan siswa dengan perangkat pembelajarannya belum mampu mengoptimalkan proses pembelajaran sehingga hasil yang diharapkan belum terlihat. Ketidakmampuan siswa Sekolah Menengah Atas (SMA) dalam hal menulis faktanya nyata. Hal ini terlihat dari karya tulis yang dihasilkan, baik dalam bentuk tulisan ilmiah maupun tulisan nonilmiah, misalnya surat pribadi, catatan buku harian, jawaban pertanyaan esai berstruktur, menulis paragraf, dan cerpen (cerita pendek) dengan topik yang ditentukan.

Rendahnya kemampuan menulis siswa antara lain disebabkan oleh belum terlaksananya hakikat pembelajaran menulis. Proses belajar-mengajar menulis di semua level pendidikan ternyata lebih banyak berpusat pada segala sesuatu tentang menulis. Siswa lebih banyak mendapat teori-teori tentang format, tata cara, dan kaidah-kaidah penulisan. Kalaupun ada latihan-latihan penerapan kemampuan menulis tersebut dilaksanakan ternyata hanyalah sebatas bimbingan siswa agar

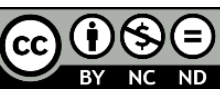

Creative Commons Attribution-NonCommercial-NoDerivatives 4.0 International License 
terampil menulis dengan format, tata cara dan kaidah-kaidah yang dimaksud, kemudian dikaitkan dengan pola berbahasa yang baik dan benar. Dalam kenyataannya kemampuan siswa menulis cerita pendek yang rendah mungkin disebabkan oleh berbagai faktor, misalnya ketidakmampuan siswa dalam mengoptimalkan kecerdasan interpersonal yang ada pada dirinya selain kemampuan siswa dalam menguasai diksi yang masih rendah.

Faktor kedua yang dapat memengaruhi kemampuan menulis siswa adalah penguasaan diksi. Menurut Keraf "diksi mempunyai ruang lingkup terkait arti kata untuk mewakili sebuah gagasan dan penggunaan kelompok kata atau ungkapan yang sesuai situasi. Fungsi diksi adalah lambang gagasan secara verbal, membentuk ekspresi gagasan yang tepat, terciptanya komunikasi yang baik dan benar, serta mencegah salah pemahaman" (Keraf, 2008).

Pemilihan kata dalam menulis cerita pendek sangat dibutuhkan karena diksi inilah yang memberikan keunikan. Diksi yang bervariatif pun akan memberi makna yang indah. Ketepatan dan kesesuaian diksi akan memberi corak yang khas dalam setiap cerita karena kata-kata yang digunakan bukanlah kata formal. Kata-kata yang digunakan adalah kata yang memiliki kebebasan. Kebebasan menggunakan kata yang masih ada unsur bahasa daerah, seperti kata yang dipahami dan digunakan oleh siswa sehari-hari.

Menurut Sayuti “cerpen secara kualitas bersifat compression/pemadatan, concentration/pemusatan, dan intensity/pendalaman, terkait dengan kualitas struktural yang tersirat pada panjang cerita" (Sayuti, 2000). Pendapat lain mengenai cerita pendek dikemukakan oleh Strong dalam Tarigan, "cerita pendek menumbuhkan minat yang besar pada diri masyarakat untuk membacanya." (Tarigan, 1991). Hal itu karena sifat cerpen yang disuguhkan dengan singkat dan lengkap. Pengarang sastra dapat menulis dan menuangkan pikiran secara cepat dan simpel. Pembaca juga dapat menikmati karya sastra tanpa waktu yang lama.

Nurgiyantoro menyatakan bahwa "cerpen mempunyai kelebihan yang khas, yaitu mengemukakan dengan lebih banyak, secara implisit dari sekadar apa yang diceritakan" (Nurgiantoro, 2002). Sumardjo dan Saini menjelaskan bahwa "cerpen mempunyai beberapa ciri, yaitu ceritanya pendek, rekaan, dan naratif. Kelengkapan sebuah cerpen dapat dilihat dari unsur-unsur pembentuknya. Unsur pembentuk itu adalah tema, alur cerita, tokoh, tema, suasana (mood dan atmosfer cerita), latar (setting), sudut pandang (point of view), dan gaya (style)" (Sumardjo \& Saini, 1997).

Tema, "Tema dipandang sebagai dasar arti atau gagasan dasar umum sebuah karya. Tema merupakan pemersatu seluruh rangkaian fakta" (Sugihastuti, 2002). Tema merupakan cerminan motif dan penentu hadirnya peristiwa, konflik, situasi dalam karya sastra. Tema mengikat seluruh unsur pembentuk dari dalam atau intrinsik sebuah karya sastra. Alur Cerita/Plot, alur cerita ialah peristiwa yang saling berhubungan. Hubungan itu terjalin berdasarkan urutan waktu, kejadian, dan sebab-akibat sehingga membentuk satu kesatuan dalam sebuah prosa fiksi. Stanton dalam Nurgiyantoro mengemukakan bahwa plot merupakan urutan kejadian secara sebab-akibat. Dengan demikian, alur atau plot adalah jalinan peristiwa-peristiwa dalam prosa fiksi yang saling berhubungan sebab-akibat (Nurgiantoro, 2002). 
Penokohan, penokohan ialah citraan yang dilukiskan atau digambarkan dari seseorang dalam sebuah cerita. Latar, latar menurut Kenney dalam Sugihastuti meliputi gambaran geografis, termasuk topografi, pemandangan, dan perincian perlengkapan sebuah ruang. Latar merupakan satu kesatuan dengan unsur yang lain dalam karya sastra, seperti waktu tertentu dan tempat tertentu (Sugihastuti, 2002). Menurut Nurgiyantoro latar terbagi menjadi tiga unsur, yaitu a) Latar tempat, lokasi terjadinya peristiwa. b) Latar waktu, kapan terjadinya sebuah peristiwa. c) Latar sosial, merujuk pada suatu tempat terkait perilaku sosial masyarakatnya. Latar merupakan kebiasaan hidup, adat-istiadat, tradisi, pandangan hidup, keyakinan, cara berpikir, dan bersikap (Nurgiantoro, 2002). Sudut pandang, merupakan cara pengarang untuk mengemukakan cerita terkait posisi tertentu terhadap tokoh-tokoh dalam cerita. Gaya bahasa dan nada, gaya bahasa merupakan menulis indah, maka gaya/style adalah keahlian untuk menulis kata-kata secara indah. Gaya Bahasa dapat berbentuk, menghidupkan benda mati, perbandingan, dan tidak sewajarnya dalam melukiskan sesuatu yang nantinyan digunakan sebagai nada.

Berdasarkan beberapa pendapat tersebut, maka kemampuan menulis cerita pendek adalah keterampilan berpikir kreatif, mengembangkan ide dan imajinasinya seluas-luasnya, memindahkan perasaan dengan memanfaatkan grafologi, struktur bahasa, kosakata, diksi dan menggunakan simbol-simbol dalam menceritakan secara kronologis tentang kehidupan seorang tokoh dengan tetap memperhatikan struktur, kemenarikan, mekanistik, akumulatif, dan keunikan sebuah cerita pendek. Karakteristik suatu cerita pendek, antara lain memiliki tema, alur, penokohan, latar, sudut pandang, dan gaya bahasa.

Kemampuan menulis seorang siswa dapat dilihat pada beberapa indikator (ciri-ciri) yang dimilikinya. Akhadiah menyebutkan beberapa indikator kemampuan menulis, antara lain kesesuaian isi dengan tema, unsur intrinsik, kosakata, struktur kalimat, dan ejaan. Berdasarkan beberapa pendapat tersebut, maka yang dijadikan sebagai acuan penilaian kemampuan menulis cerita pendek seseorang dalam penelitian ini, terdiri atas beberapa aspek seperti: 1) kesesuaian isi dengan tema, 2) unsur intrinsik, 3) kosakata, 4) struktur kalimat, dan 5) ejaan (Akhadiah et al., 1988).

Kecerdasan/inteligensi secara etimologi berasal dari bahasa Latin "intelligence" yang berarti menghubungkan atau menyatukan satu sama lain (to organize, to relate, to bind together) (Wardiana, 2004). Pengertian inteligensi memberikan bermacam-macam arti bagi para ahli yang meneliti. Kecerdasan adalah konsep yang bisa diamati, tetapi sulit untuk didefinisikan. Hal ini terjadi karena inteligensi tergantung pada konteks atau lingkungannya.

Berikut ini beberapa ahli psikologi yang mencoba memberikan pengertian tentang inteligensi. Alfred Binet yang dikutip oleh Safaria adalah seorang tokoh perintis pengukuran inteligensi, beliau menjelaskan bahwa inteligensi merupakan 1) Kemampuan untuk menetapkan tujuan yang ingin dicapainya (goal setting). 2) Kemampuan untuk menyesuaikan diri pada lingkungan. 3) Kemampuan untuk autokritik, atau mampu mengevaluasi diri sendiri secara objektif (Safaria, 2005).

Menurut Thorndike (1874-1949) seperti yang dikutip oleh (Prawira, 2012), psikolog Amerika Serikat mengklasifikasikan kecerdasan menjadi tiga tipe, yaitu kecerdasan riil (concrete intelligence), kecerdasan abstrak (abstract intelligence), 
dan kecerdasan sosial (social intelligence). Kecerdasan riil adalah kemampuan dalam beradaptasi terhadap situasi-situasi dan benda-benda riil. Kecerdasan abstrak adalah kemampuan untuk mengerti kata-kata, bilangan-bilangan, huruf-huruf, simbol-simbol, rumus-rumus, dan lain-lain. Kecerdasan sosial adalah kemampuan individu untuk bereaksi terhadap situasi-situasi sosial di masyarakat. Berdasarkan pendapat-pendapat di atas, dapat disarikan bahwa kecerdasan adalah sikap intelektual yang mencakup kecepatan memberikan jawaban, penyelesaian, dan kemampuan menyelesaikan masalah di lingkungan sekitarnya.

Kecerdasan interpersonal merupakan modal yang diakibatkan ketidakbisaan manusia untuk hidup sendiri. Howard Gardner dalam Suparno mengemukakan tentang teori kecerdasan ganda yang biasa disebut dengan multiple intelligences yang terdiri atas sembilan kecerdasan yang salah satunya adalah kecerdasan interpersonal (Suparno, 2004). Edward L. Thorndike dalam Safaria menyebutkan bahwa kecerdasan interpersonal atau kecerdasan sosial, diartikan keterampilan dan kemampuan dalam menciptakan, membangun, dan mempertahankan relasi sosialnya sehingga dalam situasi menang atau menguntungkan (Safaria, 2005). Pendapat lain, kecerdasan interpersonal merupakan kemampuan berhubungan dengan orang-orang di sekitarnya dengan memahami perasaan, temperamen, suasana hati, maksud, dan keinginan orang lain dan menanggapinya secara layak (Lwin, Lyen, \& Sim, 2008).

Terkait diksi, dirumuskan lima indikator penguasaan diksi. Indikatorindikator tersebut adalah sebagai berikut:

a. Dapat membedakan kata denotatif dan konotatif. Kosasih menjelaskan bahwa makna denotasi adalah kata yang sesuai dengan konsep awalnya, sedangkan konotasi adalah kata yang berubah akibat perasaan dan pikiran seseorang pada hal-hal tertentu (Kosasih, 2013).

b. Dapat menentukan kata yang bersinonim dan berantonim. Sinonim menurut Keraf adalah kata-kata yang bermakna sama, seperti buku, kitab, dan pustaka; sekolah dan madrasah; reklame dan iklan (Keraf, 2008). Antonim merupakan lawan kata, seperti baik lawan dari buruk.

c. Dapat membedakan kata umum dan kata khusus. Kata umum dan kata khusus dilihat dari luas tidaknya cakupan maknanya. Jika sebuah kata mengacu hal yang luas, maka disebut kata umum. Bila pada hal-hal yang khusus dan konkret, maka disebut kata khusus (Keraf, 2008).

d. Dapat menggunakan kata-kata indra. Peraba (dingin, basah, kasar, geli, dan sebagainya); perasa (pedas, pahit, asam, manis, dan sebagainya); penciuman (asam, pesing, basi, anyir, dan sebagainya); pendengaran (dengung, deru, dengking, dan sebagainya); penglihatan (kilat, becek, pudar, corak, dan sebaginya) merupakan contoh kata-kata untuk menyatakan pengalaman yang dirasakan pancaindra (Keraf, 2008).

e. Dapat membedakan kata-kata ilmiah dan populer. Menurut Keraf, kata-kata populer adalah kata-kata yang dimengerti oleh seluruh lapisan masyarakat. Kata-kata ilmiah adalah kata-kata yang biasa dipakai kaum terpelajar dalam tulisan-tulisan ilmiah (Keraf, 2008). 
Diksi atau pilihan kata mengandung pengertian bahwa pemilihan kata yang tepat sehingga terjadi kebenaran, kejelasan, keefektifan, keselarasan dan cocok untuk situasi tertentu serta membentuk pengelompokkan kata yang serumpun, harmonis, ungkapan, gaya yang tepat untuk menimbulkan nuansa makna, dan nilai rasa. Berdasarkan pemaparan di atas terkait kecerdasan interpersonal, diksi, dan cerita pendek (cerpen) perlu diadakan pengujian keterkaitan ketiganya. Hal itu perlu dilakukan untuk menunjang proses belajar-mengajar, khususnya mata pelajaran Bahasa Indonesia, lebih tepatnya materi tentang cerpen.

\section{METODE}

Metode penelitian yang digunakan adalah survei dengan teknik korelasional. Variabel terikat, yaitu kemampuan menulis cerita pendek siswa (Y) dan dua variabel bebas, yaitu: kecerdasan interpersonal $\left(\mathrm{X}_{1}\right)$ dan penguasaan diksi $\left(\mathrm{X}_{2}\right)$. Teknik pemilihan sampel adalah gabungan antara proporsional dan acak. Dalam menentukan jumlah anggota sampel dari setiap sekolah digunakan teknik proporsional, sedangkan untuk menentukan anggota sampel dari setiap sekolah dipilih secara acak. Menurut Roscoe dalam Sugiyono mengatakan bahwa "bila pada sebuah penelitian akan melakukan analisis multivariate (korelasi atau regresi ganda), maka jumlah sampel minimal 10 kali jumlah variabel yang akan diteliti (minimal 30 orang sampel)."(Sugiyono, 2013). Berdasarkan pendapat tersebut, jumlah responden ditetapkan sebanyak 60 orang siswa, yaitu siswa kelas XI SMAN 4, SMAN 20, dan SMAN 25 masing-masing 20 siswa.

\section{HASIL DAN PEMBAHASAN}

Data dari kecerdasan interpersonal diperoleh berdasarkan hasil angket/ kuesioner. Angket terdiri dari 30 butir pernyataan dengan 60 orang responden. Tiap item diberi skor dari 1 sampai 5 menurut skala Likert (preferential scale).

Tabel 1. Deskripsi Data Penelitian

\begin{tabular}{|l|r|r|r|}
\hline \multicolumn{4}{|c|}{ Statistics } \\
& $\begin{array}{c}\text { Kecerdasan } \\
\text { Interpersonal }\end{array}$ & $\begin{array}{c}\text { Penguasaan } \\
\text { Diksi }\end{array}$ & $\begin{array}{c}\text { Kemampuan } \\
\text { Menulis } \\
\text { Cerita Pendek }\end{array}$ \\
\hline Malid $\quad$ Missing & 60 & 60 & 60 \\
Mean & 0 & 0 & 0 \\
Median & 113.15 & 21.07 & 81.82 \\
Mode & 114.00 & 22.00 & 82.00 \\
Std. Deviation & 118 & $18=$ & 82 \\
Skewness & 6.592 & 3.204 & 3.322 \\
Std. Error of Skewness & -.125 & -.181 & -.138 \\
Kurtosis & .309 & .309 & .309 \\
Std. Error of Kurtosis & -.984 & -1.339 & -.825 \\
Minimum & .608 & .608 & .608 \\
Maximum & 100 & 15 & 75 \\
\hline
\end{tabular}

a. Multiple modes exist. The smallest value is shown 
Berdasarkan tabel, skor maksimum 125 sementara skor minimum 100. Tingkat kecerdasan interpersonal berada pada angka rata-rata 113,15, deviasi standar 6,59, median 114 dan modus 118 . Angka deviasi standar 6,59 berarti 5,8\% dari skor rata-rata. Disparitas kecerdasan interpersonal relatif cukup rendah, maka dapat disimpulkan bahwa tingkat kecerdasan interpersonal bersifat homogen.

Tabel 2. Rekapitulasi Hasil Pengujian Normalitas

\begin{tabular}{|ll|r|r|r|}
\hline \multicolumn{1}{|c|}{ One-Sample Kolmogorov-Smirnov Test } \\
\hline & & $\begin{array}{c}\text { Kecerdasan } \\
\text { Interpersonal }\end{array}$ & $\begin{array}{c}\text { Penguasaan } \\
\text { Diksi }\end{array}$ & $\begin{array}{c}\text { Kemampuan } \\
\text { Menulis } \\
\text { Cerita Pendek }\end{array}$ \\
\hline $\mathrm{N}$ & Mean & 60 & 60 & 60 \\
Normal Parameters & & 113.15 & 21.07 & 81.82 \\
& Std. Deviation & 6.592 & 3.204 & 3.322 \\
Most Extreme Differences & Absolute & .087 & .147 & .078 \\
& Positive & .086 & .147 & .060 \\
Kolmogorov-Smirnov Z & Negative & -.087 & -.137 & -.078 \\
Asymp. Sig. (2-tailed) & & .674 & 1.142 & .603 \\
\hline
\end{tabular}

a. Test distribution is Normal.

Pada tabel terlihat bahwa nilai pada kolom Sig dengan menggunakan metode Kolmogorov-Smirnov berturut-turut 0,$753 ; 0,147$ dan 0,860 yang berarti semua nilai $p$ value-nya $\left(\mathrm{Sig}\right.$ ) lebih besar dari 0,05 , sehingga $\mathrm{H}_{0}$ diterima dan $\mathrm{H}_{1}$ otomatis ditolak dan dapat disimpulkan bahwa semua sampel berdistribusi normal.

Hasil perhitungan pengujian linieritas garis regresi hubungan antara variabel bebas kecerdasan interpersonal terhadap variabel terikat kemampuan menulis cerita pendek dapat dilihat pada tabel di bawah ini.

Tabel 3. Hasil Pengujian Linieritas Garis Regresi Pengaruh Kecerdasan Interpersonal $\left(\mathbf{X}_{1}\right)$ terhadap Kemampuan Menulis Cerita Pendek (Y)

\begin{tabular}{|c|c|c|c|c|c|c|c|}
\hline \multicolumn{8}{|c|}{ ANOVA Table } \\
\hline & & & $\begin{array}{c}\text { Sum of } \\
\text { Squares }\end{array}$ & df & Mean Square & $\mathrm{F}$ & Sig. \\
\hline \multirow{5}{*}{$\begin{array}{l}\text { Kemampuan Menulis } \\
\text { Cerita Pendek* } \\
\text { Kecerdasan } \\
\text { Interpersonal }\end{array}$} & Between Groups & (Combined) & 356.533 & 25 & 14.261 & 1.647 & .087 \\
\hline & & Linearity & 273.042 & 1 & 273.042 & 31.528 & .000 \\
\hline & & Deviation from Linearity & 83.492 & 24 & 3.479 & .402 & .989 \\
\hline & Within Groups & & 294.450 & 34 & 8.660 & & \\
\hline & Total & & 650.983 & 59 & & & \\
\hline
\end{tabular}

Pada Tabel tersebut terlihat bahwa nilai pada kolom Sig baris Deviation from Linearity adalah 0,989 lebih besar dari 0,05, sehingga $\mathrm{H}_{0}$ diterima dan $\mathrm{H}_{1}$ ditolak. Dengan kata lain dapat dikatakan bahwa garis regresi pengaruh variabel kecerdasan interpersonal $\left(\mathrm{X}_{1}\right)$ terhadap variabel kemampuan menulis cerita pendek $(\mathrm{Y})$ tersebut bersifat linier. Hasil perhitungan pengujian linieritas garis regresi hubungan antara variabel bebas penguasaan diksi $\left(\mathrm{X}_{2}\right)$ terhadap variabel terikat kemampuan menulis cerita pendek (Y) dapat dilihat pada tabel berikut ini: 
Tabel 4. Hasil Pengujian Linieritas Garis Regresi Pengaruh Penguasaan Diksi $\left(\mathbf{X}_{2}\right)$ terhadap Kemampuan Menulis Cerita Pendek (Y)

\begin{tabular}{|c|c|c|c|c|c|c|c|}
\hline \multicolumn{8}{|c|}{ ANOVA Table } \\
\hline & & & $\begin{array}{c}\text { Sum of } \\
\text { Squares }\end{array}$ & df & Mean Square & $\mathrm{F}$ & Sig. \\
\hline \multirow{5}{*}{$\begin{array}{l}\text { Kemampuan Menulis } \\
\text { Cerita Pendek* } \\
\text { Penguasaan Diksi }\end{array}$} & \multirow[t]{3}{*}{ Between Groups } & (Combined) & 413.580 & 11 & 37.598 & 7.602 & .000 \\
\hline & & Linearity & 348.924 & 1 & 348.924 & 70.548 & .000 \\
\hline & & Deviation from Linearity & 64.656 & 10 & 6.466 & 1.307 & .254 \\
\hline & \multicolumn{2}{|l|}{ Within Groups } & 237.403 & 48 & 4.946 & & \\
\hline & \multicolumn{2}{|l|}{ Total } & 650.983 & 59 & & & \\
\hline
\end{tabular}

Pada Tabel tersebut terlihat bahwa nilai pada kolom Sig baris Deviation from Linearity adalah 0,254 lebih besar dari 0,05 , sehingga $\mathrm{H}_{0}$ diterima dan $\mathrm{H}_{1}$ otomatis ditolak. Dengan kata lain dapat dikatakan bahwa garis regresi pengaruh variabel penguasaan diksi $\left(\mathrm{X}_{2}\right)$ terhadap variabel kemampuan menulis cerita pendek $(\mathrm{Y})$ tersebut bersifat linier.

Tabel 5 Hasil Perhitungan Koefisien Korelasi Pengaruh Variabel Kecerdasan Interpersonal $\left(X_{1}\right)$ dan Penguasaan Diksi $\left(X_{2}\right)$ terhadap Variabel Kemampuan Menulis Cerita Pendek (Y)

\begin{tabular}{|l|l|r|r|r|}
\multicolumn{5}{c|}{ Model Summary } \\
\hline $\begin{array}{l}\text { Mode } \\
1\end{array}$ & $\mathrm{R}$ & R Square & $\begin{array}{c}\text { Adjusted R } \\
\text { Square }\end{array}$ & $\begin{array}{c}\text { Std. Error of } \\
\text { the Estimate }\end{array}$ \\
\hline 1 & $.824^{\mathrm{I}}$ & .679 & .667 & 1.916 \\
\hline
\end{tabular}

a. Predictors: (Constant), Penguasaan Diksi, Kecerdasan Interpersonal

Tabel 6. Rekapitulasi Hasil Perhitungan Pengujian Signifikansi Koefisien Regresi Pengaruh Variabel Kecerdasan Interpersonal $\left(X_{1}\right)$ dan Penguasaan Diksi $\left(\mathbf{X}_{2}\right)$ terhadap Variabel Kemampuan Menulis Cerita Pendek (Y)

ANOVA ${ }^{b}$

\begin{tabular}{|rr|r|r|r|r|r|}
\hline Madel & & Sum of & df & Mean Square & F & Sig. \\
\hline 1 & Regression & 441.821 & 2 & 220.910 & 60.201 & $.000^{=}$ \\
& Residual & 209.163 & 57 & 3.670 & & \\
& Total & 650.983 & 59 & & & \\
\hline
\end{tabular}

a. Predictors: (Constant), Penguasaan Diksi, Kecerdasan Interpersonal

b. Dependent Variable: Kemampuan Menulis Cerita Pendek

Tabel 7. Rekapitulasi Hasil Perhitungan Persamaan Garis Regresi Pengaruh Variabel Kecerdasan Interpersonal $\left(\mathbf{X}_{1}\right)$ dan Penguasaan Diksi $\left(\mathbf{X}_{2}\right)$ terhadap Variabel Kemampuan Menulis Cerita Pendek (Y)

\begin{tabular}{|c|c|c|c|c|c|c|}
\hline \multicolumn{7}{|c|}{ Coefficients ${ }^{\mathrm{s}}$} \\
\hline \multirow[b]{2}{*}{ Mad } & & \multicolumn{2}{|c|}{ Unstandardized Coefficients } & \multirow{2}{*}{$\begin{array}{c}\begin{array}{c}\text { Standardized } \\
\text { Coefficients }\end{array} \\
\text { Beta } \\
\end{array}$} & \multirow[b]{2}{*}{$t$} & \multirow[b]{2}{*}{ Siq. } \\
\hline & & B & Std. Error & & & \\
\hline \multirow[t]{3}{*}{1} & (Constant) & 45.917 & 4.291 & & 10.702 & .000 \\
\hline & $\begin{array}{l}\text { Kecerdasan } \\
\text { Interpersonal }\end{array}$ & .209 & .042 & .415 & 5.031 & .000 \\
\hline & Penguasaan Diksi & .580 & .086 & .560 & 6.782 & .000 \\
\hline
\end{tabular}

a. Dependent Variable: Kemampuan Menulis Cerita Pendek 
Berdasarkan tabel di atas, koefisien korelasi ganda memengaruh variabel bebas kecerdasan interpersonal $\left(\mathrm{X}_{1}\right)$ dan penguasaan diksi $\left(\mathrm{X}_{2}\right)$ secara bersamasama terhadap kemampuan menulis cerita pendek siswa (Y) adalah sebesar 0,824. Koefisien determinasinya ( $\mathrm{R}$ square) sebesar 0,679 menunjukan bahwa besarnya kontribusi kecerdasan interpersonal dan penguasaan diksi secara bersama-sama terhadap kemampuan menulis cerita pendek adalah sebesar 67,9\%, sisanya (sebesar $32,1 \%$ ) disebabkan faktor lainnya.

Untuk pengujian hipotesis melalui analisis regresi diperoleh hasil perhitungan seperti yang terlihat pada Tabel 6 dan Tabel 7. Berdasarkan Tabel 7 diperoleh persamaan garis regresi yang mempresentasikan pengaruh variabel kecerdasan interpersonal $\left(\mathrm{X}_{1}\right)$ dan penguasaan diksi $\left(\mathrm{X}_{2}\right)$ terhadap variabel kemampuan

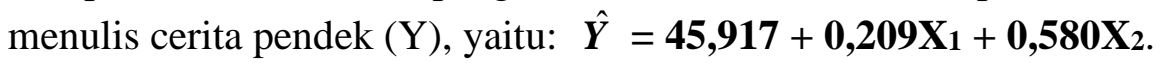

Sementara untuk menguji signifikansi garis regresi tersebut adalah dengan memperhatikan hasil perhitungan yang ada pada Tabel 6 . Menurut ketentuan yang ada, kriteria signifikansi regresi tersebut adalah "jika nilai Sig $<0,05, \mathrm{H}_{0}$ ditolak dan $\mathrm{H}_{1}$ diterima" atau "jika $\mathrm{F}_{\text {hitung }}>\mathrm{F}_{\text {tabel }} \mathrm{H}_{0}$ juga ditolak/ $\mathrm{H}_{1}$ diterima", yang berarti bahwa koefisien regresi tersebut signifikan. Dengan kata lain kita dapat simpulkan bahwa terdapat pengaruh yang signifikan variabel bebas kecerdasan interpersonal $\left(\mathrm{X}_{1}\right)$ dan penguasaan diksi $\left(\mathrm{X}_{2}\right)$ terhadap variabel terikat kemampuan menulis cerita pendek (Y). Nilai signifikansi (Sig) adalah bilangan yang tertera pada kolom Sig dalam Tabel 6 . Nilai $F_{\text {hitung }}$ adalah bilangan yang tertera pada kolom $F$ dalam tabel yang sama. Nilai $F_{\text {tabel }}$ adalah nilai tabel distribusi $F$ untuk taraf nyata 5\% dengan derajat pembilang $(\mathrm{k})=2$ dan derajat penyebut $(\mathrm{n}-\mathrm{k}-1)=57$, dengan $\mathrm{n}$ adalah jumlah banyaknya responden dan $\mathrm{k}$ adalah jumlah banyaknya variabel bebas.

Dari Tabel 6, terlihat bahwa nilai Sig $=0,000<0,05$ dan $F_{\text {hitung }}=60,201$, maka $\mathrm{H}_{0}$ ditolak dan $\mathrm{H}_{1}$ otomatis diterima yang berarti bahwa koefisien regresi tersebut signifikan. Jadi, dapat dikatakan bahwa terdapat pengaruh yang signifikan antara variabel bebas kecerdasan interpersonal $\left(\mathrm{X}_{1}\right)$ dan penguasaan diksi $\left(\mathrm{X}_{2}\right)$ secara bersama-sama terhadap kemampuan menulis cerita pendek (Y). Berdasarkan hasil pengujian korelasi maupun regresi tersebut maka disimpulkan bahwa terdapat pengaruh variabel bebas kecerdasan interpersonal $\left(\mathrm{X}_{1}\right)$ dan penguasaan diksi $\left(\mathrm{X}_{2}\right)$ secara bersama-sama terhadap kemampuan menulis cerita pendek siswa (Y).

Dari Tabel 7 terlihat bahwa nilai Sig adalah 0,000 $<0,05$ dan $t_{\text {hitung }}=5,031$, maka $\mathrm{H}_{0}$ ditolak dan $\mathrm{H}_{1}$ otomatis diterima, yang berarti terdapat pengaruh yang signifikan variabel bebas $\mathrm{X}_{1}$ (kecerdasan interpersonal) terhadap variabel terikat $\mathrm{Y}$ (kemampuan menulis cerita pendek). Dari Tabel 7 terlihat bahwa nilai Sig adalah $0,000<0,05$ dan $t_{\text {hitung }}=6,782$, maka $\mathrm{H}_{0}$ ditolak dan $\mathrm{H}_{1}$ otomatis diterima, yang berarti terdapat pengaruh yang signifikan variabel bebas $\mathrm{X}_{2}$ (penguasaan diksi) terhadap variabel terikat $\mathrm{Y}$ (kemampuan menulis cerita pendek).

\section{SIMPULAN}

1. Terdapat pengaruh yang signifikan kecerdasan interpersonal dan penguasaan diksi secara bersama-sama terhadap kemampuan menulis cerita pendek. Hal tersebut dibuktikan dengan nilai Sig. 0,000 $<0,05$ dan $\mathrm{F}_{\text {hitung }}=60,201$. 
2. Terdapat pengaruh yang signifikan kecerdasan interpersonal terhadap kemampuan menulis cerita pendek. Hal tersebut dibuktikan dengan nilai Sig. 0,000 $<0,05$ dan $t_{\text {hitung }}$ $=5,031$.

3. Terdapat pengaruh yang signifikan penguasaan diksi terhadap kemampuan menulis cerita pendek. Hal tersebut dibuktikan dengan nilai Sig. $0,000<0,05$ dan $t_{\text {hitung }}=6,782$.

\section{DAFTAR PUSTAKA}

Akhadiah, S., Arsjad, M. G., \& Ridwan, S. H. (1988). Pembinaan kemampuan menulis bahasa Indonesia. Jakarta: Erlangga.

Arifin, E. Z., \& Tasai, S. A. (2009). Cermat berbahasa Indonesia. Jakarta: Akademika Pressindo.

Keraf, G. (2008). Diksi dan gaya bahasa (Cet. XVIII). Jakarta: Gramedia Pustaka Utama.

Kosasih, E. (2013). Cerdas berbahasa Indonesia untuk SMA/MA kelas X. Jakarta: Erlangga.

Lwin, A. K., Lyen, K., \& Sim, C. (2008). Cara mengembangkan berbagai komponen kecerdasan (C. Sujana, ed.). Yogyakarta: Indeks.

Nurgiantoro, B. (2002). Teori pengkajian fiksi. Yogyakarta: Gadjah Mada University Press.

Prawira, P. A. (2012). Psikologi pendidikan: Dalam perspektif baru. Yogyakarta: Ar-Ruzz Media.

Safaria, T. (2005). Interpersonal intelligence: Metode pengembangan kecerdasan anak. Yogyakarta: Amara Books.

Sayuti, S. (2000). Kajian fiksi. Yogyakarta: Gama Media.

Sugihastuti, S. (2002). Kritik sastra feminis: Teori dan aplikasinya. Yogyakarta: Pustaka Pelajar.

Sugiyono. (2013). Statistika untuk penelitian. Bandung: Alfabeta.

Sumardjo, J., \& Saini, K. M. (1997). Apresiasi kesusastraan. Jakarta: Gramedia Pustaka Utama.

Suparno, P. (2004). Teory intelligensi ganda dan aplikasinya di sekolah. Yogyakarta: Kanisius.

Tarigan, H. G. (1991). Prinsip-prinsip dasar sastra. Bandung: Angkasa.

Wardiana, U. (2004). Psikologi umum. Jakarta: Pusat Bina Ilmu. 